\section{Ks. Zdzisław Żywica}

Uniwersytet Warmińsko-Mazurski, Olsztyn

zjzywica@poczta.onet.pl

DOI: http://dx.doi.org/10.12775/BPTh.2017.009
Biblica

et

Patristica

Thoruniensia

10 (2017) 2: 197-209

ISSN (print) 1689-5150

ISSN (online) 2450-7059

\title{
Sumienie w Duchu Świętym w świetle Rz 9,1
}

\section{Conscience in the Holy Spirit in the Light of Rom 9,1}

Streszczenie. W Rz 9,1 Paweł demonstracyjne obwieszcza osobistą prawość jako sługa Jezusa Chrystusa i Apostoł Ewangelii Bożej $(1,1)$. Na świadków uwierzytelniających prawdziwość wydanego o sobie świadectwa powołuje trzy autonomiczne podmioty: Chrystusa, sumienie, Ducha Świętego. Chrystus jest jego Panem, on zaś Jego sługą. Jako sługa jest przepełniony prawda swego Pana. Chrystus Pan jest wiarygodnym świadkiem jego prawości, ponieważ jest On jej źródłem w nim. Prawdziwość powyższego wyznania potwierdza jego sumienie. Jako wewnętrzny autonomiczny trybunał (wspót-świadek) jest $\mathrm{w}$ stanie rozpoznać dobro i zło zgodnie $\mathrm{z}$ wymogami poznanej prawdy Chrystusa - wiedzy dzielonej z Bogiem. Z tej racji posiada ono autorytet oraz władzę by na jej podstawie skutecznie zbawczo oskarżać i osądzać wszystkie myśli, słowa i działania Apostoła, rozstrzygając definitywnie czy są one z nią zgodne czy też nie; tym samym czy są dobre czy też złe w ocenie Boga, konsekwentnie, czy zamykają bądź też otwierają drogę do wiecznej Jego chwały. Duch Święty jest kreatorem prawości Apostoła, czyli panującej w nim harmonijnej zgodności wszystkich jego słów i czynów, myśli świadomości (ja/nous) i sumienia z prawdą Chrystusa będącą zbawczą wolą Boga realizowaną w Kościele mocą Jego Ducha, ponieważ badając głębie Boga (1 Kor 2,10), doskonale zna prawdę Chrystusa, którą z kolei, badając sumienie, odnawia je nią i ożywia. Duch Święty zatem według Apostoła pełni rozstrzygającą rolę w kreowaniu i autoryzowaniu jego osobistej prawości oraz jako trzeci Świadek potwierdza z absolutną pewnością wiarygodność dwóch poprzednich.

Abstract. In Rom 9,1, Paul demonstratively proclaims personal righteousness as a servant of Jesus Christ and the Apostle of the Gospel (1:1). Three autonomous entities: Christ, conscience and the Holy Spirit are called the witnesses authenticating the truthfulness of the testimony given. Christ is his Lord, and he is his servant. As a servant he is filled with the truth of his Lord. Christ the Lord is a credible witness of his righteousness, because he is its source in him. The truth of the above confession is confirmed by his conscience. As an internal autonomous tribunal (co-witness) is able to recognize good and evil according to the requirements of the known truth of Christ - sharing with God. For this reason, it possesses the respect and authority to accuse and judge effectively on its basis all the thoughts, words and actions of the Apostle, resolving 
definitively whether they are compatible with it or not; by the same, whether they are good or bad in the judgment of God, consequently, if they close or open the way to his eternal glory. The Holy Spirit is the creator of the righteousness of the Apostle, the harmonious coherence of all his words and deeds, the thoughts of consciousness (I/nous) and conscience with the truth of Christ, the salvific will of God realized in the Church by the power of his Spirit, (1 Kor 2:10) knows the truth of Christ perfectly, which, in turn, examining the conscience, renews it and animates it. The Holy Spirit, therefore, according to the Apostle, plays a decisive role in the creation and authorization of his personal righteousness and as the third witness confirms with absolute certainty the credibility of the two previous.

Słowa klucze: Chrystus; prawda; Duch Święty; sumienie; świadek; autonomia; prawość; nieomylność; Kościół.

Keywords: Christ; truth; Holy Spirit; conscience; witness; autonomy; probity; infallibility; Church.

$\mathrm{W}$ Liście do Rzymian Paweł stosuje trzykrotnie termin syneidēsis (sumienie): w pierwszej i trzeciej sekcji probatio $(2,15 ; 9,1)$ oraz w części napomnień $(13,5)^{1}$. Po raz drugi czyni to w sekcji zawartej w rozdziałach 9-11, $\mathrm{w}$ jednostce retorycznej zredagowanej jako exordium do probatio 9,6-11,312.

1 Punktem wyjścia dla prowadzonych analiz egzegetycznych jest kompozycja Listu zaproponowana przez J.-N. Aletti (List do Rzymian, s. 1411n): Praescriptum (1,1-7); Exordium (1,8-17) kończące się Propositio do całego Listu (1,16-17); Probatio składające się z trzech sekcji tematycznych: A) Żyda i Greka usprawiedliwia jedynie wiara (1,18-4,25),B) Noweżycieinadzieja ochrzczonych (5-8),C)Izraelipoganie:przyszłośćIzraela (9-11); Napomnienia (12,1-15,13); Peroratio (15,14-21); Informacje i pozdrowienia końcowe $(15,22-33+16,1-27)$, z Postscriptum w 15,33.

2 J.-N. Aletti, (List do Rzymian, s. 1445) przedstawia następującą kompozycję retoryczną sekcji 9-11: Exordium: zagadka sytuacji Izraela (9,1-5); Probatio: Izrael a poganie $(9,6-$ 11,36), składające się z trzech jednostek argumentacyjnych zredagowanych w kompozycji koncentrycznej ABA', z których każda rozwija tezę podaną we własnym propositio $(9,6 \mathrm{a} ; 10,4$; 11,1a). Jednostka A (9,6-29) ma charakter teologiczny. W propositio do niej $(9,6 a)$ Paweł potwierdza niezawodność słowa Bożego i w związku z tym faktem w argumentacji wykazuje, że obecna sytuacja Izraela nie wynika z błędu w Bożym planie zbawienia, gdyż na to nie pozwala niezgłębiona mądrość wyborów Bożych. Jednostka $B(9,30-10,21)$ ma natomiast charakter chrystologiczny. W propositio $(10,4)$ Apostoł potwierdza, że zbawienie otrzymuje się jedynie przez wiarę w Jezusa Chrystusa i dlatego wykazuje w argumentacji, że obecna sytuacja Izraela wynika z faktu odrzucenia przez niego Chrystusa - jedynej drogi zbawienia - i dalszego trwania w wierności Torze. Jednostka A' $(11,1-31)$ podobnie jak jednostka A ma charakter teologiczny. W propositio $(11,1 \mathrm{a})$ Paweł kategorycznie zapewnia, że Bóg nie odrzucił swojego ludu. Stąd też w argumentacji konsekwentnie wykazuje, że Bóg wykorzysta 
W 9,1, w odróżnieniu od pozostałych zastosowań w Liście, Apostoł odnosi własne sumienie do Ducha Świętego. Zasadnie możemy więc zapytać, co chce w ten sposób zakomunikować swoim czytelnikom w Rzymie? Co nowego chce dodać do znanego im greckiego rozumienia syneidèsis w tym konkretnym kontekście, patrząc na nie z perspektywy chrześcijańskiej? Jeśli taką właśnie ma intencję, to jaki nowy sens i funkcję chce mu nadać przez odniesienie go do Ducha Świętego? Przede wszystkim jednak należy zapytać, czy według niego Duch Święty w ogóle może mieć wpływ na sumienie i dokonywać w nim jakichkolwiek zmian, nie podważając jego suwerenności i autonomiczności? Jeśli jednak wolno $\mathrm{Mu}$ i jest w stanie ich dokonać, to jakie mogą one mieć oddziaływanie na osobę Apostoła, na jego myśli, słowa i działania, a w konsekwencji tego, na jego relacje $\mathrm{z}$ adresatami? Co $\mathrm{w}$ takim razie $\mathrm{z}$ jego, deklarowaną wielokrotnie, prawością?

\section{Kontekst: Izrael i poganie - przyszłość Izraela $(9,1-11,36)$}

Głównym tematem całej sekcji jest sytuacja Izraela i pogan w Bożym planie zbawienia. Paweł nie skupia się tu jednak na buncie Izraela i jego winie za odrzucenie Jezusa i Ewangelii, lecz bardziej zabiega o wyjaśnienie przyszłości złożonych mu przez Boga obietnic, trwałości planu zbawienia oraz prawdziwości i wierności Jego słowa. A zatem w centrum argumentacji nie stawia narodu wybrania, lecz samego Boga który go wybrał oraz Jego relacje z nim i Poganami na przestrzeni całych dziejów zbawienia. Stara się połączyć rzeczywistości z pozoru nie do pogodzenia ze sobą: sprawiedliwość dla wszystkich oraz wybór, sprawiedliwość i zatwardziałość ${ }^{3}$.

W jednostce argumentacyjnej A (9,6-29) Apostoł wykazuje niezawodność słowa Bożego, choć obecna sytuacja Izraela mogłaby na to nie wskazywać. Zatwardziałość, w jaką popadł i trwa Izrael nie jest - w jego przekonaniu skutkiem konieczności wynikającej z działania części narodu. Przeciwnie, jest dziełem samego Bożego słowa, które to działanie w niczym jednak nie szkodzi powołanym ${ }^{4}$. Tezę tę udowadnia odwołując się do dziejów Izraela. Wychodzi od epoki patriarchów (Abrahama, Izaaka, Jakuba i Ezawa) i zmierza przez czas Wyjścia (Mojżesza i Faraona) do powołaniu Pogan i Judeochrześcijan

w swoim planie zbawczym odmowę i zatwardziałość pewnej części Izraela do ostatecznego jej zbawienia. Całość sekcji zamyka peroratio (11,33-36), gdzie Apostoł wyraża swój podziw i uwielbienie dla mądrości Bożej w realizacji zbawienia całego stworzenia.

3 Por. J.-N. Aletti, List do Rzymian, s. 1445n.; H. Schlier, Der Römerbrief, s. 282n.

4 Por. J.-N. Aletti, List do Rzymian, s. 1446. 
jako „Reszty”, która to jest szczególnym dowodem niezawodności słowa Bożego w jego czasach. Zdaniem Apostoła powołania i niepowołania nie można zrozumieć w oderwaniu od siebie. Boże powołanie wyprzedza każdą ludzką odpowiedź, pozytywną bądź negatywną, i nie jest przez nią zdeterminowane. Bóg okazując gniew z powodu odmowy człowieka nie jest zatem niesprawiedliwy, ponieważ Jego wybór nie jest związany z ludzką odpowiedzią. Byłaby w tym niesprawiedliwość, gdyby chodziło o zapłatę, która zawsze następuje po ludzkim działaniu. Bóg powołuje również osoby, które okazują $\mathrm{Mu}$ nieposłuszeństwo. Postępuje tak, aby wyrazić w ten sposób wolność swojego wyboru i powołania. Dlatego w planie zbawienia wybór i powołanie nie tylko nie są sobie przeciwstawne, ale się nawzajem uzupełniają. Jako absolutnie wolny może okazać cierpliwość wobec grzeszników w tym celu, by ostatecznie zamiast potępienia obdarzyć ich łaską miłosierdzia. Dlatego też suwerennie realizuje swój plan zbawienia okazując cierpliwość wobec części Izraela, aby dzięki temu obdarzyć pogan miłosierdziem. Przecież od początku dziejów zbawienia mówi, że tylko od Jego miłosierdzia zależy wybór tych, których on dotyczy. Dla Pawła niepowołanie Pogan i surowość wobec części Izraela są bardziej oznakami Jego cierpliwości niż gniewu i potępienia. Niepowołanie zatem - w jego najgłębszym przekonaniu - zdarza się po to, aby podtrzymać Boży plan zbawienia, w którym nie ma miejsca na przypadek czy pomyłkę. Jest natomiast miejsce na wolność ludzką, która na żadnym jego etapie nie została zanegowana ${ }^{5}$.

$\mathrm{W}$ argumentacji zaprezentowanej w jednostce B $(9,30-10,21)$ Paweł wykazuje, że część Żydów znalazło się w aktualnej sytuacji zbawczej, ponieważ woleli pozostać przy dotychczasowej drodze sprawiedliwości - ekonomii Prawa, odrzucając usprawiedliwienie w Jezusie Chrystusie - ekonomię wiary. Jest dla niego oczywiste, że od przyjścia Jezusa tylko wiara w Niego i życie Ewangelią jest jedyną drogą zbawienia dla wszystkich bez wyjątku - dla każdego Żyda i każdego Poganina. Prawo Mojżeszowe osiągnęło bowiem swój ostateczny cel, czyli Bożą sprawiedliwość, w przyjściu Jezusa i darze Ducha Świętego. Odtąd nie ma już dwóch dróg zbawienia, oddzielnej dla Żydów i oddzielnej dla Pogan $^{6}$, lecz istnieje tylko jedna droga zbawienia dla wszystkich, a jest nią Jezus Chrystus i Ewangelia. Żydzi, żeby dostąpić usprawiedliwienia i zbawienia, muszą zatem przestać uważać Prawo za ich drogę zbawiania, albowiem Prawo nie daje już życia. To ono samo przecież zapowiadało tajemnicę wiary - Jezusa Chrystusa zmarłego i zmartwychwstałego - w którym wszyscy ludzie zostali przez Boga usprawiedliwieni i w Nim też dostąpią zbawienia. Ekonomia wiary

5 Por. Rz 2; J.-N. Aletti, List do Rzymian, s. 1447-1449; H. Schlier, Der Römerbrief, s. 289-305; H. Langkammer, List do Rzymian, s. 121-132.

6 Jak chcieliby tego zatwardziali Żydzi. 
jest więc dla Pawła całkowitym przeciwieństwem ekonomii Prawa. Dla niego sens słowa wiara, od wydarzenia zbawczego w Jezusie, to wewnętrzna obecność Chrystusa w każdym wierzącym w Niego, wraz z jej zbawczymi skutkami. To żywa obecność Syna, w którym objawiła się w pełni sprawiedliwość Ojca i jest ona udzielana przez Niego w imieniu Syna zarówno Żydom, jak i Poganom. Dlatego już wierzący w Jezusa Żydzi („Reszta”) nie muszą poddawać się Prawu Mojżeszowemu, by osiągnąć zbawienie i życie. Z zaprezentowanej argumentacji jasno więc wynika, że wiara w Jezusa ma dla Apostoła nie tylko istotne znaczenie dla usprawiedliwienia, lecz również dla zbawienia wiecznego ${ }^{7}$.

W trzeciej części argumentacji A' $(11,1-32)$ Apostoł wielokrotnie odnosi się do wzajemnych relacji: Izrael-Poganie, które w radykalny sposób zostały zrewidowane przez łaskę miłosierdzia okazaną obu stronom w zbawczym dziele Jezusa, co ma zasadnicze znaczenie dla ich ostatecznego losu w Bożym planie. Czyni to w tym celu, aby potwierdzić przede wszystkim wierność Boga $\mathrm{w}$ wypełnianiu danych obietnic, że nie odrzuci swego ludu i nie pozostawi go bez zbawienia, czego niewątpliwym dowodem jest wybrana i powołana do zbawienia „Reszta”. Zatem obecne wyobcowanie tej części narodu, która odrzuciła Jezusa i Ewangelię, nie jest ostateczne. Paweł dowodzi, że skoro Bóg wszczepił dziką gałązkę w szlachetne drzewo oliwne, czyniąc Pogan w pełni dziećmi Abrahama zdolnymi do wydania szlachetnych owoców ${ }^{8}$, to tym bardziej jest w mocy zaszczepić na świętym drzewie gałązki pierwotnie należące do niego, które to zostały tymczasowo odcięte z powodu niewiary i tymczasowo odsunięte ze względu na zatwardziałość. Nadzwyczaj dobitnie wyraża więc swe przekonanie w kwestii powołania do zbawienia Pogan, które można w pełni zrozumieć jedynie w odniesieniu do Izraela zatwardziałego (odcięte gałązki) lub Izraela wybranego (święty korzeń). Według niego Poganie, wierzący w Jezusa, nie mogą więc zaistnieć $\mathrm{w}$ pełni w Bożym planie bez Izraela, bez posiadania błogosławieństwa Abrahama i jego potomstwa. Gdyby zatem Poganie odcięli się od dziedzictwa Izraela związanego $\mathrm{z}$ wiarą Patriarchy, to odcięliby się tym samym od własnej historii i tożsamości.

Poganie potrzebują zatem Izraela, by stać się dziedzicami Abrahama, ale też i cieleśni synowie Patriarchy - zatwardziała część Izraela - potrzebują Pogan, by mogli dostąpić zbawienia. Dlatego też Apostoł trzykrotnie oświadcza, że wiara w Jezusa i przyjęcie Ewangelii przez Pogan wzbudzi zazdrość w wiernych

7 Por. Rz 2; J.-N. Aletti, List do Rzymian, s. 1449-1451; H. Schlier, Der Römerbrief, s. 305-320; H. Langkammer, List do Rzymian, s. 132-141.

8 Dzięki Temu Poganie otrzymali od Boga dar powołania oraz ostateczną i nierozerwalną więź jak łączy ich z błogosławieństwem udzielonym Patriarchom. Por. J.-N. Aletti, List do Rzymian, s. 1452. 
Prawu Żydach $(11,11.14)$. Owa zazdrość nie tylko nie powiedzie ich ku złemu, lecz zgodnie z Bożym zamysłem pobudzi ich do podjęcia dobrych działań. Skoro bowiem tak gorliwie trwają przy Prawie, to dlaczego nie mieliby w tej gorliwości zacząć zazdrościć Poganom ich gorliwego trwania przy Chrystusie i Ewangelii. A jeśli ten sam Bóg doprowadził Pogan do wiary w Jezusa, w którego to Boga i oni przecież tak gorliwie wierzą, to dlaczego nie miałby On i ich doprowadzić, przez żywioną przez nich gorliwość i zazdrość o Boga, do wiary w Chrystusa Pana. Przecież już teraz, pozostając każda ze stron przy swoim, to jednak wspólnie wypełniają przykazania miłości Boga i bliźniego, świadczą o Jego miłosierdziu oraz wymaganiach biblijnego monoteizmu. Jeśli więc rzeczywiście tak już się dzieje, to jest to bezsporny dowód na to, że ten sam Bóg dał się poznać Poganom, i że teraz przez nich daje się poznać i innym, czego dowodem są kolejni Poganie wyznający wiarę w Jezusa budując Jego Kościół. Paweł wyraźnie dowodzi w ten sposób, że Żydzi potrzebują Kościoła Jezusa po to, aby to dzięki jego świadectwu poznali w jaki sposób Boże miłosierdzie objawia się wszystkim, bez jakiejkolwiek dyskryminacji którejkolwiek ze stron dziejów zbawienia (11,31). Nie tylko więc „Reszta” Izraela i już wierzący w Jezusa Poganie dostępują zbawienia, lecz dzięki ich świadectwu, dzięki wierze Kościoła, jaki tworzą, ostatecznie wejdzie do niego pełnia Pogan. A gdy faktycznie tak się stanie, to - zgodnie z planem zbawienia - również dotąd odsunięci Żydzi, kierując się gorliwym trwaniem w wierze i zazdrościa o swego Boga, uwierzą również w posłanego przez Niego Jezusa Chrystusa jako Pana, co poskutkuje, że $\mathrm{w}$ ten oto, przewidziany przez Boga, sposób cały Izrael dostąpi zbawienia $(11,26)^{9}$.

\section{Tłumaczenie $9,1-5$}

$9{ }^{1}$ Prawdę mówię w Chrystusie, nie kłamię, wspót-świadczy mi o tym moje sumienie w Duchu Świętym, ${ }^{2} \dot{z}$ e mam wielki smutek i nieustanny ból w moim sercu. ${ }^{3}$ Wolałbym bowiem ja sam być wyklęty $z$ dala od Chrystusa za braci moich, tych krewnych moich według ciała, ${ }^{4}$ którymi sa Izraelici, do których należy usynowienie, i chwała, i przymierza i nadanie Prawa, i służba, i obietnice. ${ }^{5}$ Ich sa Ojcowie, i z nich jest Chrystus według ciała, Ten, który jest nad wszystkimi, Bóg, niech będzie uwielbiony na wieki. Amen.

9 Por. J.-N. Aletti, List do Rzymian, s. 1451-1454; L.T. Johnson, Reading Romans, s. 148-152; H. Schlier, Der Römerbrief, s. 320-348; H. Langkammer, List do Rzymian, s. $142-153$. 


\section{Egzegeza $9,1^{10}$}

\subsection{Prawda w Chrystusie}

9,1: Apostoł rozpoczyna exordium znaną mu $\mathrm{z}$ retoryki klasycznej formułą: „prawdę mówię" (alētheian legōo) ${ }^{11}$. Jednak tym, co ją zdecydowanie od niej odróżnia, jest umieszczone w niej odniesienie do najwyższego autorytetu zewnętrznego, w tym przypadku do osoby Chrystusa: „W Chrystusie” (en Christō $)^{12}$. W tak nadzwyczaj uroczystym stylu i podniosłym tonie oświadcza, że jest członkiem mistycznego Ciała Chrystusa (Kościoła) i dlatego będzie przemawiał nie we własnym, lecz Chrystusa imieniu. Z tego zaś wynika, że każde jego słowo będzie posiadało Jego uwierzytelnienie, autorytet. Otwarcie odnosi więc osobistą szczerość i prawdomówność do prawdomówności (prawdy) Chrystusa, odwołując się zapewne do 2 Kor 11,10, gdzie wyraził swe głębokie przekonanie, że prawda Chrystusa jest we nim. Gdy oświadcza zatem Kościołowi w Rzymie, że słowa, które kieruje do niego, są prawdziwe, to daje jednoznacznie do zrozumienia, że prezentowana tu przez niego postawa i wypowiadane słowa w pełni odpowiadają wymogom Ewangelii Jezusa. Tym samym więc czyni Chrystusa najbardziej wiarygodnym świadkiem swej osobistej szczerości i prawdomówności nie tylko przed Kościołem, ale i przed samym Bogiem. Ewentualny sceptycyzm Kościoła co do prawdomówności Apostoła mógłby przeczyć jego innemu przekonaniu, a mianowicie o mistycznej więzi, jaka łączy wszystkich chrześcijan między sobą: „Tym zaś, który umacnia nas wespół z wami w Chrystusie, i który nas namaścił, jest Bóg” (2 Kor 1,21) ${ }^{13}$. Gdyby rzeczywiście pojawił się taki sceptycyzm w postawie wiernych Kościoła, to oznaczałoby, że występując przeciwko Apostołowi, występują tym samym przeciwko Bogu i Chrystusowi, niszcząc ich dzieło dokonywane w świecie i Kościele mocą Ducha Świętego i Ewangelii ${ }^{14}$.

Pierwsze zapewnienie o osobistej prawdomówności Apostoł wzmacnia kolejnym. Tym razem sformułowanym w formie negatywnej: „nie kłamię” (ou

10 R. Jewett, (A Commentary, s. 556) proponuje następujący podział tej jednostki retorycznej: 9,1-3 i 9,4-5.

11 Por. 2 Kor 12,6.

12 Por. Rz 1,9; 2 Kor 1,23; 11,31 (12,19); Ga 1,20; 1 Tm 2,7.

13 Por. R. Jewett, Commentary, s. 557; H. Schlier, Der Römerbrief, s. 284.

14 Por. H. Schlier, Der Römerbrief, s. 284. 
pseudomai) ${ }^{15}$. Dzięki tak skonstruowanej kompozycji umieszcza on odniesienie do Chrystusa (en Xristō) pośrodku dwóch kategorycznych zapewnień, tworząc w ten sposób strukturę koncentryczną. Czyni to zapewne w tym celu, aby z jeszcze większą siłą retoryczną oznajmić, że to osoba samego Chrystusa jest autorytetem potwierdzającym i uwierzytelniającym jego osobistą prawdziwość, nie zaś on sam - nawet przyobleczony w autorytet apostolski jaśniejący wieloma wyjątkowymi przymiotami ${ }^{16}$. Biorąc pod uwagę fakt, że w 3,4 stwierdza, iż wszyscy ludzie są kłamcami, to odwołanie się do Chrystusa w tym miejscu, w sytuacji gdy chodzi o jego osobę, każe widzieć w tym zamiar odsunięcia podobnego oskarżenia skierowanego przeciwko niemu $\mathrm{z}$ tej istotnej racji, że jest on członkiem Kościoła, a więc trwa w mistycznym związku z Chrystusem, a przez Niego również z Bogiem. Ten zaś fakt wyklucza w sposób absolutnie niepodważalny jakikolwiek brak szczerości i prawdy w Apostole; jest w tym podobny do Chrystusa.

\subsection{Autonomia sumienia}

Fraza skonstruowana w genetivus absolutus: „współ-świadczy mi o tym moje sumienie w Duchu Świętym", dodaje jeszcze jedno, niezależne od poprzednich, świadectwo uwierzytelniające szczerość i prawość Apostoła. Czasownik współ-świadczyć (symmartyrousēs) ${ }^{17}$ odnosi się do sumienia (syneidēsis) ${ }^{18}$. A zatem Apostoł odwołuje się tu do sumienia jako autonomicznego wspót-świadka, który zna jego wewnętrzne myśli i motywy postępowania, czyli zna jego stan świadomości (ja/nous). Wspót-świadek sumienie osądza stan jego świadomości (ja/nous) w świetle prawdy Chrystusa. Jej właśnie, a nie jakichkolwiek innych zasad czy norm etycznych bądź prawnych, ponieważ to na nią wskazuje, bezpośrednio odnosząc się do osoby Chrystusa (en Xristō). To On z woli Boga ogłosił ją jako pierwszy, a obecnie, z woli tego samego Boga, głosi ją Jego Apostoł w imieniu Chrystusa jako moc Boża $(1,16)$ w miejsce Tory i tradycji judaistycznej. W sumieniu widzi on więc wewnętrzną autonomiczną instancję (dyspozycję) zdolną rozpoznać w nim samym dobro i zło zgodnie z przyjętą i wyznawaną prawdą Chrystusa. Posiada ono autorytet oraz władzę, by na jej

\footnotetext{
15 Podobne zwroty występują w retoryce klasycznej. Por. R. Jewett, Commentary, s. 558.

16 To samo zaprzeczenie występuje w 2 Kor 11,31 i Ga 1,20, gdzie Apostoł odwołuje się do Boga i Jezusa mówiąc o swoim postępowaniu.

17 Symmartyrein: wspótświdczyć, poświadczać wraz z kimś, dawać świadectwo wraz $z$ kimś, zaświadczać razem z kimś.

18 Podobnie jak w Rz 2,15.
} 
podstawie skutecznie zbawczo oskarżać i osądzać jego myśli, słowa i działania, rozstrzygając definitywnie czy są one zgodne z jej wymogami czy też nie; czy są dobre czy też złe w ocenie Boga. Autonomiczność sumienia potwierdza też fakt, że pierwsze dwa czasownika mają za podmiot Apostoła; to on (ja Paweł) wyznaje: „prawdę mówię” ... „nie kłamię”. Natomiast podmiotem trzeciego jest sumienie, które niezależnie od ja Apostoła, autonomiczne choć jednocześnie będące jego (mou), wspót-świadczy (symmartyrousēs) wraz z aktualnie posiadaną przez Apostoła świadomościa (ja) o absolutnej prawdziwości tego, co pisze ${ }^{19}$.

\subsection{Sumienie odnawiane mocą Ducha Świętego w prawdzie Chrystusa}

Nie tylko zaimek moje (mou) w wyrażeniu moje sumienie (syneidēseōs mou) wskazuje na jego autonomiczną naturę, lecz również eksponuje ten aspekt odniesienie go do Ducha Świętego (en pneumati hagiō). Zwrot $w$ Duchu Świętym ${ }^{20}$ w tym konkretnym kontekście mógłby być rozumiany w tym sensie, że sumienie działa niejako w imieniu Ducha albo też jakby miało być bezpośrednio kontrolowane bądź wprost prowadzone przez Niego. W takiej sytuacji aktywnym podmiotem dawanego świadectwa byłby Duch Święty, sumienie zaś byłoby jedynie biernym Jego narzędziem. Według Pawła jednak sumienie może być omylne $^{21}$. To zaś każe odrzucić powyższą interpretację, gdyż w całej swej nauce o Duchu Świętym jednoznacznie zaświadcza o Jego nieomylności ${ }^{22}$. Uwzględniając kontekst poprzedzający 9,1, należy zasadnie przyjąć, że wyjawia on tu swe najgłębsze przekonanie, iż jego autonomiczne sumienie wydaje świadectwo całkowicie zgodne z wolą Bożą objawioną w prawdzie Chrystusa i jest w nim nieomylne, ponieważ wydaje je $w$ Duchu Świętym (en pneumati hagiō). Zatem Duch Święty jest według niego autonomicznym podmiotem, który jednak może z zewnątrz oddziaływać na syneidēsis. W żadnym go nie zastępuje, ale ma moc kreowania i podtrzymywania w nim jego prawości, czyli harmonijnej zgodności norm, jakimi się posługuje z wolą Bożą objawioną w Jezusie prawdą Chrystusa i Syna Bożego. W przypadku Pawła jego sumienie jest prawe odkąd poznał Ewangelię Bożą i wyznał wiarę w Jezusa oraz całkowicie poddał się dalszemu przewodnictwu Ducha Bożego, który napełnia go coraz głębszym poznaniem prawdy Chrystusa. Argumenty za takim właśnie stanem jego ja/ nous i syneidēsis podaje w poprzednim rozdziale, gdzie wykazuje, że dzięki Du-

19 Por. H. Schlier, Der Römerbrief, s. 284.

20 Zwrot $w$ Duchu Świętym występuje jeszcze w Rz 5,5; 14,17; 15,13.16; 1 Kor 6,19;

12,3; 2 Kor 6,4.6; 13,13; 1Tes 1,5.6; 4,8; Tt 3,5; Ef 1,13; 4,30. Por. też 1QSb 2,24.

21 Por. 1 Kor 8,7.10.12.

22 Por. H. Schlier, Der Römerbrief, s. 284n. 
chowi ochrzczeni mogą żyć i mieć nadzieję, gdyż On prowadzi ich i ożywia (8,3-17). To dzięki Niemu są zdolni do działania etycznego, które prowadzi do życia w chwale $(8,12-13)$. Obecne cierpienia, choć prowadzą do grzechu, to ostatecznie nie pomniejszą przyszłej chwały, gdyż Duch przychodzi z pomocą ochrzczonym w ich ludzkiej słabości $(8,26-27)$. W czasie jej doświadczania mogą stać się niezdolnymi do wiernego wypełniania woli Bożej, ale pomimo tego Duch daje im moc czynienia dobra zgodnego z Ewangelią, gdyż jest On życiem i obietnicą zmartwychwstania, udziału w chwale Chrystusa z którym są przecież na stałe zjednoczeni przez wiarę i chrzest $(8,11)$. Ochrzczeni powinni mieć świadomość, że w doświadczeniach sam Duch rozwija w nich życie wiary i pobudza do postępowania etycznego, które staje się świadectwem działania w nich mocy Ewangelii Bożej $(1,16)$. To zaś jest dowodem na to, że nie należą już do kategorii grzeszników znajdujących się w rozpaczliwej sytuacji opisanej w 7,7-25 i nie podlegają potępieniu. To sam Duch życia mieszkający w ochrzczonych i prowadzący ich, uwalnia i wyprowadza ich ze statusu grzeszników, pomimo doświadczanych słabości ${ }^{23}$. Nadto, w 1 Kor 2,10 Apostoł jednoznacznie stwierdza, że: „Duch bada wszystko, także głębie Boga” ${ }^{4}$, co nie pozostawia najmniejszych wątpliwości, że jest On w mocy przenikać również świadomość ( $j a /$ nous) i sumienie ludzkie ${ }^{25}$.

Powyższe argumenty pozwalają stwierdzić, że Apostoł uznaje własne oraz innych chrześcijan sumienie za już odnowione przez poznaną Ewangelię Boża $(1,16)$, czego konsekwencją było wyznanie przez nich wiary i przyjęcie chrztu. Jednak osiągnięty stan nie jest docelowym punktem dojścia, lecz otwarciem drogi do wiecznej chwały. Sumienie by dysponować skutecznością zbawczą musi nadal podlegać odnowicielskiej mocy Ducha Świętego w prawdzie Chrystusa. Zatem wiara i chrzest otwierają proces jego odnowy w celu osiągnięcia pełnej zgodności jego kryteriów osądu czynów ludzkich z wolą Bożą, przez poddanie się kierownictwu Ducha Świętego, gdyż tylko On jest w stanie tego dokonać. Widzi więc sumienie chrześcijańskie jako wewnętrzny autonomiczny trybunał

23 Por. J.-N. Aletti, List do Rzymian, s. 1442-1444.

24 Ci, którzy postępują według Ducha dąża do tego, czego chce Duch (8,6). Dążenie Ducha owocuje $\dot{z y c i e m ~}(8,7)$. Duch daje życie dzięki usprawiedliwieniu $(8,10)$. Bóg przez Duch ożywia śmiertelne ciała $(8,11)$. Duch daje życie $(8,13)$. „Ci, którzy dają się prowadzić Duchowi Boga, są synami Boga” (8,14). Duch Boży daje świadectwo naszemu duchowi, że jesteśmy dziećmi Bożymi $(8,16)$. Chrześcijanie mając pierwsze dary oczekują usynowienia, odkupienia ich ciała $(8,23)$. „Podobnie też Duch wspiera nas w naszej niemocy. Nie wiemy bowiem, o co i jak należy się modlić, ale sam Duch wstawia się za nami w błaganiach, których nie można wyrazić słowami. A Ten, który bada serca, wie, czym jest zamysł Ducha i że zgodnie z wolą Boga wstawia się On za świętymi” (8,26n).

25 Por. H. Schlier, Der Römerbrief, s. 238-281. 
(instancję), który dzięki Duchowi Świętemu dzieli z Bogiem wiedzę (prawdę Chrystusa) w kwestii zbawczej wartości wszystkich aktów ludzkich. Posiadanie, w pełnej prawdzie, owej wiedzy jest możliwe jedynie dzięki Duchowi Świętemu, gdyż tylko On bada głębie Boga (1 Kor 2,10); jest więc absolutnym gwarantem jej Boskiego pochodzenia i zgodności norm sumienia z prawdą Chrystusa, czyli poręczycielem jego niezaprzeczalnej prawości. To właśnie dzięki niej oraz mocy Ducha Świętego, a nie wiedzy i norm ludzkich, jest ono w stanie rozpoznawać dobro i zło w człowieku oraz oskarżać i osądzać wszystkie jego myśli, słowa i działania zgodnie z osądem Boga. W przekonaniu zatem Apostoła Duch Święty musi mieć zagwarantowany wolnym aktem woli ustawiczny wpływ na sumienie chrześcijańskie i stale je odnawiać swą moca w prawdzie Chrystusa. Co nie oznacza w żadnym razie, że w jakimkolwiek stopniu ogranicza jego autonomiczność ${ }^{26}$.

\section{Teologiczne przesłanie $R z$ 9,1}

\subsection{Chrystus źródłem i świadkiem prawości Pawła}

W pierwszej frazie wersetu: „Prawdę mówię w Chrystusie, nie kłamię”, Paweł nie pozostawia wątpliwości co do osobistego autorytetu oraz podmiotu go uwierzytelniającego, własnej prawości oraz jej źródła i świadka. Głęboko wierzy w to, że działa i naucza nie dla siebie, lecz dla Boga i Jezusa. Jezus jest dla niego Chrystusem, pełnym mocy Synem Bożym i Panem Kościoła ${ }^{27}$. Głęboko wierzy w to, że zawsze gdy przemawia to wypowiada nieskazitelną prawdę, bowiem każdym swoim słowem i czynem reprezentuje Chrystusa w zbawczym dziele Boga jako członek Kościoła - Mistycznego Ciała Jego Syna, w którym pełni funkcję Stugi i Apostoła $(1,1)$. Będąc pewnym swego wybrania, powołania i posłania w celu kontynuacji misji Boga w osobie Jego Syna i Pana Kościoła ma też pełne przekonanie o prawości w tym co mówi i czego dokonuje, tj. harmonijnej zgodności własnych dzieł i słów z prawdą Chrystusa i wewnętrznymi myślami jego wewnętrznych myśli świadomości (ja/nous) ${ }^{28}$. Choć Apostoł nie mówi tego wprost, to jednak zasadnie można przyjąć, iż ujawnia tu swe dogłębne przekonanie o tym, że gdy działa i przemawia w Kościele i świecie to w rzeczywistości nie czyni tego on, lecz sam Chrystus przez niego. Jest przecież

\footnotetext{
26 Por. J.M. Boice, Romans, s. 1018-1024; J.F. MacArthur, Romans 1-8, s. 258-263.

27 Por. Rz 1,1-7.

28 Ja Paweł „prawdę mówię w Chrystusie, nie kłamię”.
} 
sługą swego Pana Jezusa Chrystusa, a to decyduje o tym, że Chrystus będąc świadkiem jego prawości najpierw stał się jej źródłem.

\subsection{Sumienie i Duch Święty gwarantami i świadkami prawości Apostoła}

Struktura retoryczna drugiej części wersetu: „współ-świadczy mi o tym moje sumienie w Duchu Świętym", pozwala Pawłowi pokazać dwóch kolejnych świadków uwierzytelniających jego osobistą prawość. Czyni to zapewne w celu wzmocnienia retorycznej siły argumentacji jaką przedstawia Kościołowi. Fraza ta pod względem retorycznym nie pozostawia czytelnikom właściwie żadnych szans na przekonujące zakwestionowanie prawości Apostoła w jego integralnej postawie prezentowanej wobec nich. Obok Chrystusa stawia jeszcze dwa inne autonomiczne podmioty uwierzytelniające to, czego źródłem i świadkiem jest Jezus: to sumienie i Duch Święty. Sumienie choć jest w nim, to jednak daje ono autonomiczne świadectwo, niezależne od jego ja/nous. Jego autonomiczności, podobnie jak Chrystus, nie ogranicza w żadnym stopniu również Duch Święty. Oba podmioty wydają odrębne, autonomiczne świadectwa, które są w pełni zgodne z jego ja/nous i prawdą Chrystusa. Wspótświadcza wydając identyczne werdykty w tej samej sprawie wówczas, jeśli sumienie będzie poddane stałej odnowicielskiej mocy Ducha Świętego, który bada wszystko, nawet głębie Boga (1 Kor 2,10). Przenikając sumienie udziela mu wiedzy Boga (prawdy Chrystusa), czyli niezbywalnych, skutecznych zbawczo, kryteriów osądu wszystkich aktów ludzkich.

\section{Bibliografia}

Aletti J.-N., List do Rzymian w: Międzynarodowy Komentarz do Pisma Świętego. Komentarz katolicki i ekumeniczny na XXI wiek, W.R. Farmer (red.), tłum. M. Żurowska, Warszawa 2000, s. 1411-1455.

Barret C.K., The Epistle to the Romans. Black's New Testament Commentary, London $1991^{2}$.

Boice J.M., Romans. God and history, New Testament Commentary, v. 3, Grand Rapids 1993.

Haldane R., Exposition of the Epistle to the Romans, Escondido 1999.

Janowski B., Der Mensch im alten Israel, Zeitschrift für Theologie und Kirche, 102 (2005), s. $143-175$.

Jewett R., A Commentary on the Book of Romans, Augsburg 2007.

Johnson L.T., Reading Romans. A Literary and Theological Commentary. Reading the New Testament Series, Macon 2001. 
Langkammer H., List do Rzymian. Pismo Święte Starego i Nowego Testamentu, Lublin 1999.

MacArthur J.F., Romans 1-8. New Testament Commentary, Chicago 1994.

Schlier H., Der Römerbrief. Herders Theologischer Kommentar zum Neuen Testament. Sonderausgabe, Freiburg-Basel-Wien 2002.

Stępień J., Syneidesis (sumienie) w antropologii św. Pawła, w: Człowiek we wspólnocie Kościoła. Księga Pamiątkowa na 25 lecie ATK, red. L. Balter, Warszawa 1979, s. $162-201$.

Szymik S., Starotestamentowe, judaistyczne i grecko-rzymskie pojęcie sumienia, Forum Teologiczne XV (2014), s. 7-21. 